\title{
Microwave Assisted Synthesis of ethyl-quinolon-4-one-3-carboxylates and Hydrolysis to quinolon-4-one-3-carboxylic Acids
}

\author{
Ivana Malvacio ${ }^{1,2}$, D. Mariano. A. Vera ${ }^{2}$ and Elizabeth L. Moyano*,1 \\ ${ }^{I}$ INFIQC - Organic Chemistry Department, School of Chemical Sciences, National University of Córdoba, Córdoba, CP \\ 5000, Argentine, ${ }^{2}$ Department of Chemistry, School of Exact and Natural Sciences, National University of Mar del \\ Plata, Mar del Plata, CP 7600, Buenos Aires, Argentine
}

\begin{abstract}
A fast and efficient microwave assisted synthesis of several ethyl-quinolon-4-one-3-carboxylates and quinolon4-one-3-carboxylic acids has been developed. The 3-carboethoxy quinolones are easily obtained in a one-pot procedure through the cyclization of aminomethylenemalonate intermediates obtained by reaction of different $p$-substituted anilines and diethyl-ethoxymethylenmalonate. These quinolones are then irradiated under base hydrolysis conditions to get the carboxylic acids through a very fast and clean approach.
\end{abstract}

Keywords: Carboxylic acids, catalysis, cyclization, hydrolysis, malonates, microwave, open-vessel, quinolones, sealed-vessel, thermolysis.

\section{INTRODUCTION}

The quinolone structure is extensively used in a variety of pharmacologically active synthetic and natural compounds [1]. Among them, 4-quinolones derivatives are not only an important class of antibacterial [2], antidiabetic [3] and anticancer [4] agents but also a useful structural moiety for drug candidates [5].

All of these applications justify the effort to develop new efficient strategies to synthesize this structural moiety. However, existing synthetic methods for 3-substituted-quinol-4ones usually require multistep processes and laborious isolation of the intermediates.

Nowadays a variety of synthetic methodologies to obtain heterocycles can be explored such as metal-catalyzed couplings [6], multicomponent reactions [7] and microwaveassisted synthesis [8]. These techniques, by themselves or in combination with others, make it possible to obtain better results in a more efficient and mild way.

In recent decades, microwave-assisted organic synthesis (MAOS) has gained an important role in organic and medicinal chemistry. Microwave heating can intensely accelerate a wide range of reactions, especially when they are carried out under solvent-free conditions [9]. Microwave irradiation allows the temperature to increase uniformly throughout the sample, which minimizes the presence of undesired by-products allowing a precise control of reaction conditions [10].

As part of our continuing effort to produce heterocycles via microwave assisted reactions, we set out to develop a rapid synthetic methodology for the generation of various quinolones $[11,12]$.

*Address correspondence to this author at the INFIQC - Organic Chemistry Department, School of Chemical Sciences, National University of Córdoba, Córdoba, CP 5000, Argentine; Tel/Fax: +54 3515353867 ;

E-mail: lauramoy99@gmail.com
In this work we report an efficient microwave assisted synthesis of ethyl-quinolon-4-one-3-carboxylates using different anilines and diethyl-ethoxymethylenmalonate as starting materials. The classical synthesis of these 3-carboethoxyquinolones usually requires many hours at reflux temperatures in high-boiling-point organic solvents [13]. Our experimental approach resulted advantageous and easy to carry out in few minutes using microwaves giving very good yields of the desired quinolones. In a second step the fast hydrolysis of quinolone esters was also achieved using microwave irradiation and base conditions giving carboxylic acids in excellent yields.

\section{RESULTS AND DISCUSSION}

The synthesis of ethyl-quinolon-4-one-3-carboxylates (4) consisted of a two-step sequence that involves the initial reaction between anilines (1) and diethyl-ethoxymethylenmalonate (2) to give diethyl 2-((phenylamino)methylene) malonate derivatives (3), which eliminate ethanol affording the quinolones by a cyclization reaction (Scheme $\mathbf{1}$ ).

To carry out the reaction, an equimolar mixture of 1a-g and $\mathbf{2}$ was initially exposed to microwave irradiation at $80^{\circ} \mathrm{C}$ for $1 \mathrm{~min}$ in solvent-less conditions using a closed system (Step 1, Scheme 1). Quantitative formation (> $95 \%$ ) of diethyl malonates 3a-g was established by ${ }^{1} \mathrm{H}-\mathrm{NMR}$ analysis of the reaction mixture. These products were in excellent purity conditions to be used in the next step without isolation. It should be noted that the solvent-free preparation of 3b using microwaves was already reported in the literature ( 2 min, $70{ }^{\circ} \mathrm{C}, 97 \%$ yield); however, in this report we have expanded the scope of this chemistry to other malonate derivatives synthesis obtaining excellent yields $[14,15]$.

To optimize the reaction conditions of cyclization of diethyl malonates 3 towards quinolones 4 (Step 2, Scheme 1), 3a was selected as model reactant to perform the reaction. 


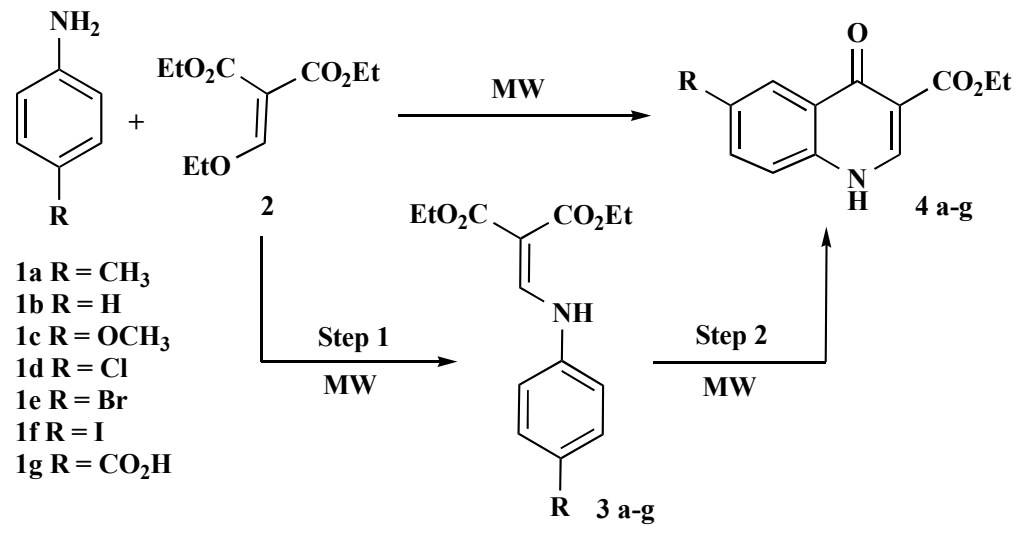

Scheme 1. Synthesis of ethyl-quinolon-4-one-3-carboxylates 4.

We started with sealed vessel reactions because they are safer and easier to perform than open systems. As a first attempt, solvent-free reaction of $\mathbf{3} \mathbf{a}$ was performed in a closed vessel. After microwave irradiation for several minutes using the maximum power irradiation $(300 \mathrm{~W})$ the temperature reached only $115{ }^{\circ} \mathrm{C}$, a low value considering that the required temperature for cyclization of malonates in conventional and microwave irradiated reactions should be higher than $220^{\circ} \mathrm{C}[13,15]$. It is known that in the case of reactions involving low microwave absorption reagents and solvents, passive heating elements can be used to improve the microwave absorption as well as the heat transfer [16]. In this regard, we tried reactions using graphite (powder $<20 \mu \mathrm{m}$, $\geq$ $99.99 \%$ purity) and silicon carbide (SiC, 200-450 mesh) as microwave susceptors. Using both additives, temperatures of reaction mixture were raised to $220-260^{\circ} \mathrm{C}$ depending on the irradiation time and amount of the absorber; however, yields of $\mathbf{4 a}$ were still low (4-26\%, entries 1-5, Table 1). In these heterogeneous experiments, open vessel reactions were also evaluated but this system did not promote any significant improvement. As an additional difficulty, total removal of graphite and $\mathrm{SiC}$ carbonaceous solids from the crude was hard and deficient mainly due to the insolubility of the quinolones in most common organic solvents.

To improve not only the microwave absorption of 3a but also its cyclization reaction to $4 \mathbf{a}$, the presence of different catalysts, $\mathrm{Ce}\left(\mathrm{NO}_{3}\right)_{3}, \mathrm{BiVO}_{4}$, bentonite, polyphosphoric acid (PPA) and $\mathrm{Na}_{2} \mathrm{CO}_{3}$ was also studied. It is known that cerium and bismuth catalyst have been applied as Lewis acid imparting high regioselectivity and chemoselectivity in various chemical processes [17]. Besides, PPA has been used as acid catalyst in the formation of several 4-quinolones [18] and $p$ chlorobenzoic acid was used in the microwave-assisted synthesis of sulfamoyl-4-oxo-quinolines [19]. Different clays were also used for solvent-free 'dry media' reactions $[9,20]$. In other approaches base catalysts were evaluated in the microwave assisted synthesis of 2-aryl-4-quinolones [21]. In our case, temperatures reached up to $250{ }^{\circ} \mathrm{C}$ for all catalyzed experiments of 3a using sealed vessel systems; however, the synthesis of the desired quinolones did not proceed efficiently. Low yields of $\mathbf{4 a}(<15 \%)$ as well as high decomposition of starting material were observed.

After that, different solvents were evaluated for the reaction: water, acetonitrile, $N, N$-dimethylformamide (DMF), 1,2-dichlorobenzene (DCB) and diphenyl ether (DPE). In the case of reactions in water and acetonitrile, temperatures were not higher than $200{ }^{\circ} \mathrm{C}$ and conversion of $\mathbf{3 a}$ was depleted. When DMF was used, temperatures raised $250{ }^{\circ} \mathrm{C}$ in $1 \mathrm{~min}$ at $300 \mathrm{~W}$, giving only $10 \%$ of $4 a$. Interestingly, acceptable yields (29-49\%) were obtained when DCB and DPE were used as solvents. In both cases longer reaction times produced a decrease in the yields favoring the formation of undesired products [14]. Better results were achieved when 3a was subjected to irradiation for $1 \mathrm{~min}$ in $\mathrm{DCB}$ at $250^{\circ} \mathrm{C}$ (entry 10 , Table 1) using a dynamic irradiation method, that is, a temperature-controlled method in which the variation of the power allowed us to reach a precise temperature value. Another irradiation method was also applied, in this case the power was fixed and the temperature oscillated within a range of $\pm 10^{\circ} \mathrm{C}$ (entries 7-9, 11-12 and 17).

In order to make a 'one-pot' procedure, the solvent (DCB) was added to the mixture of $\mathbf{1 a}$ and $\mathbf{2}$ from the beginning then, two consecutive irradiation steps were applied, the first one was $1 \mathrm{~min}$ at $80^{\circ} \mathrm{C}$ followed by $2-10 \mathrm{~min}$ at $250{ }^{\circ} \mathrm{C}$. Yields of $4 \mathbf{a}$ were identical to those obtained in two independent steps (Scheme 1), so we applied this methodology to the rest of the experiments. Additionally, the experimental protocol was very simple because quinolone 4a was isolated in pure form by simple filtration and washing.

In our case, microwave-assisted reactions performed under sealed vessel conditions were not good enough to get high yields of 4a or at least yields similar to that obtained by conventional synthesis $\left(77 \%\right.$ at $250{ }^{\circ} \mathrm{C}$ in DPE) [13]. Taking into account that one equivalent of ethanol is produced in each step of the reaction- which under atmospheric pressure conditions can be easily removed- we decided to apply microwave irradiation under open vessel conditions. The experimental arrangement was designed to closely simulate the conventional oil bath synthesis, where yields of quinolones were very good [13] (Table 3). Thus, a conical bottom flask was placed inside the cavity and was fitted with a quartz column adapter (See Supporting Information). A standard distillation kit was attached to the top of the column which, in some cases, was connected to a round bottom flask immersed in liquid air.

Different tests in open vessel indicated that ethanol should be released for shifting the equilibrium towards products. As shown in Table 1, open vessel reactions (using DFE) resulted in better yields of quinolone than closed ves- 
Table 1. Microwave conditions for the synthesis of quinolone 4a.

\begin{tabular}{|c|c|c|c|c|c|c|c|}
\hline Entry & Solvent & Additive & Reactor $^{\mathrm{a}}$ & Power (W) & Time (min) & Temp. $\left({ }^{\circ} \mathrm{C}\right)^{\mathrm{b}}$ & Yield (\%) \\
\hline 1 & - & $\mathrm{CSi}^{\mathrm{d}}$ & Sealed & $100-200$ & 10 & $220(223)$ & 7 \\
\hline 2 & - & $\mathrm{CSi}^{\mathrm{d}}$ & Sealed & $25-175$ & 2 & $260(268)$ & 26 \\
\hline 3 & - & $\mathrm{CSi}^{\mathrm{e}}$ & Open & $100-300$ & 5 & $250(258)$ & 23 \\
\hline 4 & - & Graphite $^{\mathrm{f}}$ & Sealed & $50-250$ & 2 & $250(253)$ & - \\
\hline 5 & - & Graphite $^{\mathrm{f}}$ & Open & $175-300$ & 2 & $250(255)$ & 9 \\
\hline 6 & DPE & - & Sealed & $150-300$ & 1 & $250(252)$ & 20 \\
\hline 7 & DPE & - & Sealed & 100 & 5 & $260 \pm 10$ & 23 \\
\hline 8 & DPE & - & Sealed & 200 & 5 & $260 \pm 10$ & 34 \\
\hline 9 & DPE & - & Sealed & 300 & 5 & $260 \pm 10$ & 32 \\
\hline 10 & DCB & - & Sealed & $100-250$ & 1 & $250(255)$ & 49 \\
\hline 11 & DCB & - & Sealed & 200 & 5 & $260 \pm 10$ & 33 \\
\hline 12 & DCB & - & Sealed & 200 & 10 & $260 \pm 10$ & 44 \\
\hline 13 & DPE & - & Open & $50-300$ & 5 & $250(253)$ & 57 \\
\hline 14 & DPE & - & Open & $275-300$ & 2 & $250(252)$ & 41 \\
\hline 15 & DPE & - & Open & $200-300$ & 2 & $250(251)$ & $67^{g}$ \\
\hline 16 & DPE & - & Open & $150-300$ & 1 & $260(261)$ & $55^{\mathrm{g}}$ \\
\hline 17 & DPE & - & Open & 200 & 4 & $260 \pm 10$ & $57^{\mathrm{h}}$ \\
\hline
\end{tabular}

${ }^{\mathrm{a}}$ Vessel of $10 \mathrm{~mL}$ was used in closed systems while $25 \mathrm{~mL}$ flask was used in open system. ${ }^{b}$ In parentheses, maximum temperature reached. ${ }^{\mathrm{C}} \mathrm{Yields}$ of isolated product calculated from anilines. ${ }^{\mathrm{d}}$ Molar ratio 1a: CSi was 12:1. ${ }^{\mathrm{e}}$ Molar ratio 1a: CSi was 18:1. ${ }^{\mathrm{f}}$ Molar Ratio 1a: Graphite was 11:1. ${ }^{\mathrm{g}}$ Collection receiver immersed in a liquid air bath. ${ }^{\mathrm{h}}$ Experiments carried out under air flow.

sel experiments. Although DCB was a good solvent under sealed vessel conditions, temperature was not higher than $180{ }^{\circ} \mathrm{C}$ in the open vessel conditions and starting $\mathbf{3 a}$ was obtained without any change.

It is important to highlight that the reaction performed with the flask connected to the end of the refrigerant immersed in liquid air resulted in higher yields of product. Evidently, the temperature difference between the reaction vessel and the flask outside the reactor pushed the volatile ethanol out. A similar effect was expected in reactions performed in air flow. However, this condition did not substantially improve the yields of $\mathbf{4 a}$. Also, irradiation times longer than 4 min did not improve the yields of quinolones and DPE decomposed forming undesirable products.

Up to this point, the best condition was the irradiation of 3a at $250{ }^{\circ} \mathrm{C}$ for 2 min using dynamic irradiation method (entry 15 , Table $\mathbf{1}$ ).

After that, the cyclization of malonates $\mathbf{3 b} \mathbf{b} \mathbf{g}$ was carried out applying the enhanced conditions acquired in open vessel as well as in sealed vessel experiments of 3a. These results are depicted in Table $\mathbf{2}$. It was clear that the synthesis of quinolones was favored under open vessel conditions. These findings were attributed to the fact that ethanol can be easily released promoting the reaction along the desired pathway, as it was observed in other reactions [22].
For open systems, in some cases, reaction temperatures of $250{ }^{\circ} \mathrm{C}$ gave high amount of quinolones, but the products were very impure. Therefore, optimal temperature for the synthesis of quinolones $\mathbf{4 a - g}$ was found to be $240^{\circ} \mathrm{C}$.

Furthermore, yields of $\mathbf{4 a - g}$ were improved when an excess of 2 (molar ratio 1: 2 equal to 0.5 ) was used. This behavior was also observed by Lange et al. in the microwave assisted synthesis of 3-aryl-4-hydroxyquinolin-2-ones [23]. Thus, optimal conditions for the synthesis of quinolones using DPE as solvent were found to be: $1 \mathrm{~min}$ of microwave irradiation at $80^{\circ} \mathrm{C}$ under open vessel conditions followed by 2 min of irradiation under the variable power method at 240 ${ }^{\circ} \mathrm{C}$. These conditions allowed us to obtain $\mathbf{4 a - g}$ in excellent yields, even better than preparations involving conventional heating (Table 3 ). The conventional synthesis of compounds 4a-c and 4e was carried out previously in our research group [13] and we added two new compounds, $4 \mathbf{d}$ and $\mathbf{4 f - g}$ to our library of quinolones.

In order to expand our library of quinolones we studied the hydrolysis of ethyl quinolone-carboxylates to afford quinolone carboxylic acids. The 4-quinolone-3-carboxylic acid derivatives are widely known for their use as antibacterial agents. Additionally, these types of compounds are an attractive scaffold in medicinal chemistry to obtain many quinolone derivatives, as amides which are a promising class of compounds displaying interesting biological activity as anti- 
Table 2. Yields of quinolones 4 a-f in open and sealed microwave experiments.

\begin{tabular}{|c|c|c|c|c|c|c|}
\hline \multirow{3}{*}{ Compound } & \multirow{3}{*}{$\mathbf{R}$} & \multicolumn{5}{|c|}{ Yield $(\%)^{\mathrm{a}}$} \\
\hline & & \multicolumn{4}{|c|}{ Open System ${ }^{\mathrm{b}}$} & \multirow{2}{*}{$\begin{array}{r}\text { Sealed System } \\
(260 \pm 10)^{\circ} \mathrm{C}\end{array}$} \\
\hline & & $220^{\circ} \mathrm{C}$ & $230^{\circ} \mathrm{C}$ & $240^{\circ} \mathrm{C}$ & $250^{\circ} \mathrm{C}$ & \\
\hline $4 a$ & $\mathrm{CH}_{3}$ & 10 & 34 & 66 & 67 & $49^{\mathrm{d}}$ \\
\hline $4 b$ & $\mathrm{H}$ & 25 & 58 & 75 & 62 & 32 \\
\hline $4 c$ & $\mathrm{OCH}_{3}$ & 13 & 48 & 54 & 55 & 30 \\
\hline $4 d$ & $\mathrm{Cl}$ & 4 & 36 & 80 & 82 & 44 \\
\hline $4 e$ & $\mathrm{Br}$ & 12 & 70 & 65 & 46 & 57 \\
\hline $4 f$ & I & 19 & 23 & 67 & 85 & 59 \\
\hline
\end{tabular}

${ }^{a}$ Yields of isolated product, values calculated from starting anilines. Molar ratio 1: 2 equal to 1. ${ }^{\mathrm{b}}$ Solvent: DPE, irradiation time: 3 min. ${ }^{\mathrm{c}}$ Solvent: DCB, irradiation time: 6 min. ${ }^{\mathrm{d}}$ Temperature: $250-255^{\circ} \mathrm{C}$, irradiation time: $2 \mathrm{~min}$.

Table 3. Microwave vs. conventional synthesis of quinolones 4.

\begin{tabular}{|c|c|c|c|}
\hline \multirow{2}{*}{$\mathbf{R}$} & Microwave Method $^{\mathrm{a}}$ & \multicolumn{2}{|c|}{ Conventional Method } \\
\cline { 2 - 4 } & Yield (\%) & Time (h) & Yield (\%) $^{\mathrm{c}}$ \\
\hline \hline $\mathrm{CH}_{3}$ & $79^{\mathrm{b}}(74)^{\mathrm{c}}$ & 1 & 77 \\
\hline $\mathrm{H}$ & $75^{\mathrm{b}}(68)^{\mathrm{c}}$ & 1 & 31 \\
\hline $\mathrm{OCH}_{3}$ & $68^{\mathrm{b}}(65)^{\mathrm{c}}$ & 0.75 & 58 \\
\hline $\mathrm{Cl}$ & $87^{\mathrm{b}}(82)^{\mathrm{c}}$ & 3 & 71 \\
\hline $\mathrm{Br}$ & $91^{\mathrm{b}}(83)^{\mathrm{c}}$ & 5 & 71 \\
\hline $\mathrm{I}$ & $89^{\mathrm{b}}(87)^{\mathrm{c}}$ & 3 & 63 \\
\hline $\mathrm{CO}_{2} \mathrm{H}$ & $80^{\mathrm{b}}(71)^{\mathrm{c}}$ & 1 & 63 \\
\hline
\end{tabular}

${ }^{\mathrm{a}}$ Molar ratio $1: 2$ equal to 0.5 , irradiation time: 3 min. ${ }^{b}$ Isolated product. ${ }^{c}$ Recrystallzed from DMF.

HIV agents [24] or as cannabinoid ligands, [25] among others [26].

The formation of carboxylic acids from ethyl quinolonecarboxylates is carried out under base and acid conditions and usually takes long reaction times at temperatures of solvent reflux [26]. In order to simplify the methodology, microwave irradiation was applied to achieve the hydrolysis of quinolones 4a-g. Therefore, a mixture of carboethoxy quinolones and aqueous $\mathrm{KOH}(10 \% \mathrm{w} / \mathrm{v})$ in ethanol was irradiated at $90-100{ }^{\circ} \mathrm{C}$ for $15 \mathrm{~min}$. After cooling, the mixture was acidified with concentrated $\mathrm{HCl}$ to get corresponding acids (see Table 4). Compounds 5a-f were obtained in excellent yields and hydrolysis of ester derivatives was successful; however, for compound $\mathbf{4 g}$ the corresponding acid (5g) was not detected under any experimental condition producing mainly decomposition products. This fact can be attributed to the possible instability of the dicarboxylic acid product, which can suffer other transformations under the microwave heating conditions.
Table 4. Hydrolysis of quinolones 4 in basic media.

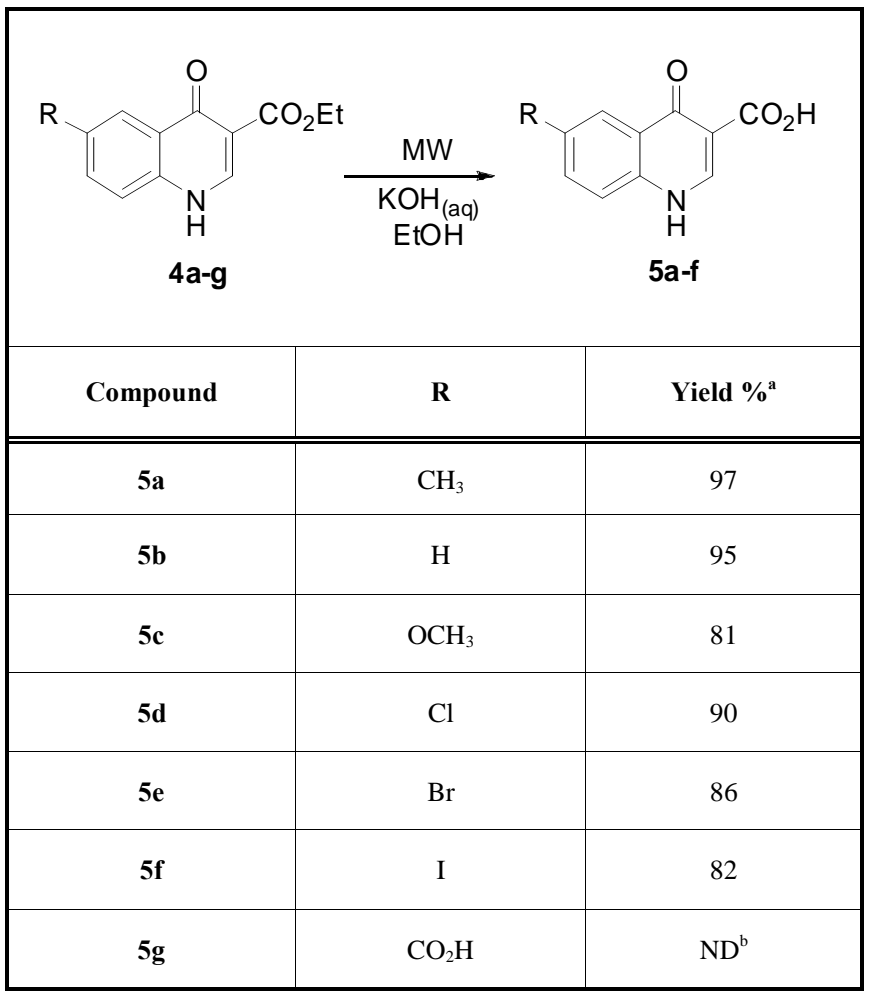

${ }^{\mathrm{a}}$ Isolated compound. ${ }^{\mathrm{b}}$ Not detected in the reaction mixture.

\section{CONCLUSION}

In this work we applied microwave irradiation to optimize the preparation of various ethyl-quinolon-4-one-3carboxylates and from these compounds the corresponding carboxylic acids in an easy and efficient protocol. At this point it is important to highlight that microwave heating reduced the reaction times for synthesis of all quinolones from 
hours to minutes improving in most of the cases the yields obtained in conventional synthesis.

\section{MATERIALS AND METHODS}

\section{(1) General Method}

All organic starting materials were analytically pure and used without further purification. Melting points are uncorrected. ${ }^{1} \mathrm{H}$ and ${ }^{13} \mathrm{C}$ NMR spectra of aminomethylenmalonates 3a-g and quinolones $\mathbf{4 g}$ and 5a-f were recorded on a Bruker Advance II $400\left({ }^{1} \mathrm{H}\right.$ at $400 \mathrm{MHz}$ and ${ }^{13} \mathrm{C}$ at $\left.100 \mathrm{MHz}\right)$ using DMSO- $d_{6}$, TFA- $d_{l}$ and $\mathrm{D}_{2} \mathrm{O}$ as solvents. The spectra of aminomethylenmalonates were identical to the previously reported [13]. ${ }^{1} \mathrm{H}$ and ${ }^{13} \mathrm{C}$ NMR spectra of quinolones $4 \mathbf{a}-\mathbf{f}$ were recorded on INOVA $600 \mathrm{MHz}$ Varian $\left({ }^{1} \mathrm{H}\right.$ at $600 \mathrm{MHz}$ and ${ }^{13} \mathrm{C}$ at $\left.150.9 \mathrm{MHz}\right)$ using $\left(\mathrm{CD}_{3}\right)_{2} \mathrm{SO}$ as solvent. Chemical shifts $(\delta)$ were referenced to TMS, and ${ }^{13} \mathrm{C}-\mathrm{NMR}$ chemical shifts $(\delta)$ were referenced to internal solvent resonance.

(2) General Procedure for the Synthesis of the ethylquinolon-4-one-3-carboxylates (4a-g)

In a typical "one pot" experiment a mixture of $0.25 \mathrm{~g}$ (2.68 - $1.14 \mathrm{mmol})$ of aniline 1a-g, diethyl-ethoxymethylenmalonate $(1.08-0.46 \mathrm{~mL})$ and DPE $(2 \mathrm{~mL})$ was irradiated with two consecutive methods. The first one was $1 \mathrm{~min}$ at 80 ${ }^{\circ} \mathrm{C}$ followed by $2 \mathrm{~min}$ at $240{ }^{\circ} \mathrm{C}$ using an open vessel (see supplementary information) to afford derivatives $\mathbf{4 a - g}$. These quinolones were precipitated in hexane $(10 \mathrm{~mL})$, the solids were collected by filtration, washed with acetone, dried, and recrystallized from DMF. The yields of $\mathbf{4 a - g}$ were calculated from starting anilines $\mathbf{1 a - g}$.

(3) General Procedure for the Synthesis of the quinolon4-one-3-carboxylic acids (5a-f)

A mixture of $0.25 \mathrm{~g}(1.15-0.73 \mathrm{mmol})$ carboethoxy quinolones (4a-f), $2 \mathrm{~mL}$ of aqueous solution of $\mathrm{KOH}(10 \% \mathrm{w} / \mathrm{v})$ and $2 \mathrm{~mL}$ of ethanol was irradiated at $90-100{ }^{\circ} \mathrm{C}$ during 15 min using an open vessel system. After cooling, the mixture was acidified with $\mathrm{HCl}(1 \mathrm{M})$ to get the corresponding acids. Finally, the solids were collected by filtration, washed with water and dried.

(4) Characterization Data of Products

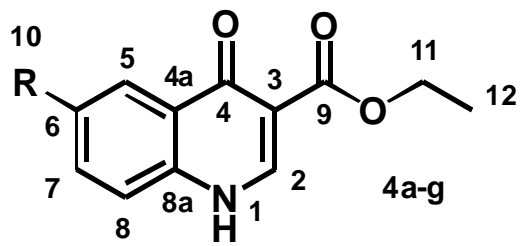

ethyl-6-methyl-4-oxo-1,4-dihydroquinoline-3-

carboxylate (4a): White solid, m.p. $>280^{\circ} \mathrm{C}$ decomposes. ${ }^{1} \mathrm{H}$ NMR $\left(600 \mathrm{MHz}\right.$, DMSO- $\left.d_{6}\right): \delta{ }_{(\mathrm{ppm})} 1.28\left(\mathrm{t}, 3 \mathrm{H}_{12}, J=7.1\right.$ $\mathrm{Hz}) ; 2.42$ (s, 3H $\left.\mathrm{H}_{10}\right) ; 4.21$ (q, $\left.2 \mathrm{H}_{11}, J=7.1 \mathrm{~Hz}\right) ; 7.51\left(\mathrm{dd}, 1 \mathrm{H}_{\mathbf{8}}\right.$, $J=8.2$ and $0.7 \mathrm{~Hz}) ; 7.53\left(\mathrm{dd}, 1 \mathrm{H}_{7}, J=8.2\right.$ and $\left.1.8 \mathrm{~Hz}\right) ; 7.95$ $\left(\mathrm{s}, 1 \mathrm{H}_{5}\right) ; 8.49\left(\mathrm{~d}, 1 \mathrm{H}_{2}, J=6.7 \mathrm{~Hz}\right) ; 12.24\left(\mathrm{~d}, 1 \mathrm{H}_{1}, J=6.7 \mathrm{~Hz}\right)$. ${ }^{13} \mathrm{C}$ NMR $\left(100 \mathrm{MHz}, \mathrm{DMSO}-d_{6}\right): \delta(\mathrm{ppm}) 14.32 ; 20.77 ; 50.44$; $109.46 ; 118.64 ; 124.91 ; 127.17 ; 133.58 ; 134.12 ; 136.91$; $144.33 ; 164.81 ; 173.23$. ethyl-4-oxo-1,4-dihydroquinoline-3-carboxylate (4b). White solid, m.p. $>250^{\circ} \mathrm{C}$ decomposes. ${ }^{1} \mathrm{H}$ NMR $(600 \mathrm{MHz}$, DMSO- $\left.d_{6}\right): \delta_{(\mathrm{ppm})} 1.28\left(\mathrm{t}, 3 \mathrm{H}_{\mathbf{1 2}}, J=7.1 \mathrm{~Hz}\right) ; 4.21\left(\mathrm{q}, 2 \mathrm{H}_{\mathbf{1 1}}, J=\right.$ $7.1) ; 7.41$ (ddd, $1 \mathrm{H}_{6}, J=8.1,7.0$ and $\left.1.1 \mathrm{~Hz}\right) ; 7.61\left(\mathrm{ddd}, 1 \mathrm{H}_{8}\right.$, $J=8.3,1.1$ and $0.6 \mathrm{~Hz}) ; 7.70\left(\mathrm{ddd}, 1 \mathrm{H}_{7}, J=8.3,7.0\right.$ and 1.5 $\mathrm{Hz}) ; 8.15$ (ddd, $1 \mathrm{H}_{5}, J=8.1,1.5$ and $\left.0.7 \mathrm{~Hz}\right) ; 8.54\left(\mathrm{~d}, 1 \mathrm{H}_{2}, J=\right.$ $6.7 \mathrm{~Hz}) ; 12.30\left(\mathrm{dd}, 1 \mathrm{H}_{1}, J=6.7\right.$ and $\left.0.7 \mathrm{~Hz}\right) .{ }^{13} \mathrm{C} \mathrm{NMR}$ $\left(\mathrm{DMSO}-d_{6}\right): \delta_{(\mathrm{ppm})} 14.31 ; 59.52 ; 109.77 ; 118.73 ; 124.64$; $125.59 ; 127.23 ; 132.35 ; 138.92 ; 144.83 ; 164.77 ; 173.38$.

ethyl-6-methoxy-4-oxo-1,4-dihydroquinoline-3carboxylate (4c). Light brown solid, m.p. $>280^{\circ} \mathrm{C}$ decompose. ${ }^{1} \mathrm{H}$ NMR $\left(600 \mathrm{MHz}, \mathrm{DMSO}-d_{6}\right): \delta_{(\mathrm{ppm})} 1.28\left(\mathrm{t}, 3 \mathrm{H}_{12}\right.$, $J=7.1 \mathrm{~Hz}) ; 3.89\left(\mathrm{~s}, 3 \mathrm{H}_{10}\right) ; 4.21\left(\mathrm{q}, 2 \mathrm{H}_{11}, J=7.1 \mathrm{~Hz}\right) ; 7.34$ $\left(\mathrm{dd}, 1 \mathrm{H}_{7}, J=8.9\right.$ and $\left.3.0 \mathrm{~Hz}\right) ; 7.57\left(\mathrm{~d}, 1 \mathrm{H}_{5}, J=3.0 \mathrm{~Hz}\right) ; 7.58$ $\left(\mathrm{d}, 1 \mathrm{H}_{8}, J=8.9 \mathrm{~Hz}\right) ; 8.49\left(\mathrm{~d}, 1 \mathrm{H}_{2}, J=6.7 \mathrm{~Hz}\right) ; 12.30\left(\mathrm{dd}, 1 \mathrm{H}_{1}\right.$, $J=6.7 \mathrm{~Hz}) .{ }^{13} \mathrm{C}$ NMR (DMSO- $\left.d_{6}\right): \delta_{(\mathrm{ppm})} 14.31 ; 55.42$; $59.44 ; 105.50 ; 106.63 ; 120.48 ; 122.14 ; 128.48 ; 133.29$; $143.58 ; 156.55 ; 164.91 ; 172.81$.

ethyl-6-chloro-4-oxo-1,4-dihydroquinoline-3carboxylate (4d). White solid, m.p. $>280^{\circ} \mathrm{C}$ decomposes. ${ }^{1} \mathrm{H}$ NMR (600 MHz, DMSO- $\left.d_{6}\right): \delta{ }_{(\mathrm{ppm})} 1.28\left(\mathrm{t}, 3 \mathrm{H}_{12}, J=7.1\right.$ $\mathrm{Hz}) ; 4.21\left(\mathrm{q}, 2 \mathrm{H}_{11}, J=7.1 \mathrm{~Hz}\right) ; 7.67\left(\mathrm{~d}, 1 \mathrm{H}_{\mathbf{8}}, J=8.8 \mathrm{~Hz}\right) ; 7.76$ $\left(\mathrm{dd}, 1 \mathrm{H}_{7}, J=8.8\right.$ and $\left.2.4 \mathrm{~Hz}\right) ; 8.08\left(\mathrm{~d}, 1 \mathrm{H}_{5}, J=2.4 \mathrm{~Hz}\right) ; 8.58$ $\left(\mathrm{d}, 1 \mathrm{H}_{2}, J=6.6 \mathrm{~Hz}\right) ; 12.5\left(\mathrm{~d}, 1 \mathrm{H}_{1}, J=6.6 \mathrm{~Hz}\right) .{ }^{13} \mathrm{C} \mathrm{NMR}$ $\left(\mathrm{DMSO}-d_{6}\right): \delta_{(\mathrm{ppm})}: 17.29 ; 59.68 ; 110.03 ; 121.24 ; 124.58$; $128.34 ; 129.34 ; 132.45 ; 137.66 ; 145.19 ; 164.53 ; 172.16$.

ethyl-6-bromo-4-oxo-1,4-dihydroquinoline-3carboxylate (4e). White solid m.p. $>300^{\circ} \mathrm{C}$ decomposes. ${ }^{1} \mathrm{H}$ NMR (600 MHz, DMSO- $\left.d_{6}\right): \delta_{(\mathrm{ppm})} 1.28\left(\mathrm{t}, 3 \mathrm{H}_{12}, J=7.1\right.$ $\mathrm{Hz}) ; 4.22\left(\mathrm{q}, 2 \mathrm{H}_{11}, J=7.1 \mathrm{~Hz}\right) ; 7.60\left(\mathrm{~d}, 1 \mathrm{H}_{\mathbf{8}}, J=8.8 \mathrm{~Hz}\right) ; 7.86$ $\left(\mathrm{dd}, 1 \mathrm{H}_{7}, J=8.8\right.$ and $\left.2.3 \mathrm{~Hz}\right) ; 8.22\left(\mathrm{~d}, 1 \mathrm{H}_{5}, J=2.3 \mathrm{~Hz}\right) ; 8.59$ $\left(\mathrm{s}, 1 \mathrm{H}_{2}\right) ; 12.5\left(\mathrm{~s}, 1 \mathrm{H}_{1}\right) .{ }^{13} \mathrm{C}$ NMR $(100 \mathrm{MHz}, \mathrm{TFA}): \delta{ }_{(\mathrm{ppm})}$ $14.43 ; 67.22 ; 107.83 ; 123.49 ; 123.67 ; 127.42 ; 129.46$; $140.44 ; 143.61 ; 147.53 ; 169.71 ; 174.89$.

ethyl-6-iodo-4-oxo-1,4-dihydroquinoline-3carboxylate (4f). White solid, m.p. $>280^{\circ} \mathrm{C}$ decomposes. ${ }^{1} \mathrm{H}$ NMR (600 MHz, DMSO- $\left.d_{6}\right): \delta_{(\mathrm{ppm})} 1.28\left(\mathrm{t}, 3 \mathrm{H}_{12}, J=7.1 \mathrm{~Hz}\right)$; $4.21\left(\mathrm{q}, 2 \mathrm{H}_{11}, J=7.1 \mathrm{~Hz}\right) ; 7.44\left(\mathrm{~d}, 1 \mathrm{H}_{8}, J=8.7 \mathrm{~Hz}\right) ; 7.99(\mathrm{dd}$, $1 \mathrm{H}_{7}, J=8.7$ and $\left.2.2 \mathrm{~Hz}\right) ; 8.42\left(\mathrm{~d}, 1 \mathrm{H}_{5}, J=2.2 \mathrm{~Hz}\right) ; 8.57(\mathrm{~d}$, $\left.1 \mathrm{H}_{2}, J=6.7 \mathrm{~Hz}\right) ; 12.40\left(\mathrm{~d}, 1 \mathrm{H}_{1}, J=6.7 \mathrm{~Hz}\right) .{ }^{13} \mathrm{C} \mathrm{NMR}$ $\left(\mathrm{DMSO}-d_{6}\right): \delta_{\text {(ppm) }} 14.29 ; 59.67 ; 89.62 ; 110.28 ; 121.17$; $128.90 ; 134.06 ; 138.30 ; 140.47 ; 145.16 ; 164.51 ; 171.94$.

3-(ethoxycarbonyl)-4-oxo-1,4-dihydroquinoline-6carboxylic acid (4g). Beige solid, m.p.: $>280^{\circ} \mathrm{C}$ decompose. ${ }^{1} \mathrm{H}$ NMR (400 MHz, TFA): $\delta(\mathrm{ppm}): 0.81\left(\mathrm{t}, 3 \mathrm{H}_{12}, J=7.2 \mathrm{~Hz}\right)$; $3.98\left(\mathrm{q}, 2 \mathrm{H}_{11}, J=7.16 \mathrm{~Hz}\right) ; 7.56\left(\mathrm{~d}, 1 \mathrm{H}_{8}, J=8.9 \mathrm{~Hz}\right) ; 8.13(\mathrm{~d}$, $\left.1 \mathrm{H}_{7}, J=8.8 \mathrm{~Hz}\right) ; 8.71\left(\mathrm{~s}, 1 \mathrm{H}_{5}\right) ; 8.75\left(\mathrm{~s}, 1 \mathrm{H}_{2}\right) .{ }^{13} \mathrm{C} \mathrm{NMR}$ (TFA) $\delta_{\text {(ppm) }}: 9.61 ; 62.58 ; 103.45 ; 117.39 ; 118.54 ; 125.86$; $127.84 ; 134.85 ; 139.41 ; 144.71 ; 164.78 ; 166.72 ; 172.01$.

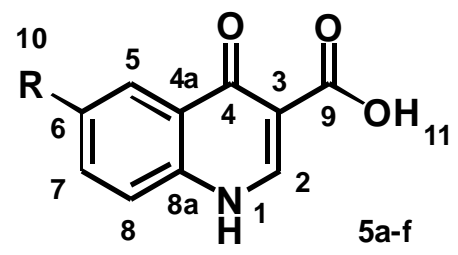

6-methyl-4-oxo-1,4-dihydroquinoline-3-carboxylic acid (5a): White solid, hygroscopic. ${ }^{1} \mathrm{H}$ NMR $(400 \mathrm{MHz}$, DMSO- $\left.d_{6}\right): \delta_{(\mathrm{ppm})} 2.49\left(\mathrm{~s}, 3 \mathrm{H}_{10}\right) ; 7.73\left(\mathrm{~s}, 1 \mathrm{H}_{\mathbf{8}}\right) ; 7.74\left(\mathrm{~s}, 1 \mathrm{H}_{7}\right)$; 
$8.10\left(\mathrm{~s}, 1 \mathrm{H}_{5}\right) ; 8.86\left(\mathrm{~s}, 1 \mathrm{H}_{2}\right) ; 13.39\left(\mathrm{~s}, 1 \mathrm{H}_{1}\right) ; 15.49\left(\mathrm{~s}, 1 \mathrm{H}_{11}\right)$.

${ }^{13} \mathrm{C}$ NMR (DMSO- $\left.d_{6}\right) \delta_{(\mathrm{ppm})} 21.27 ; 117.87 ; 119.95 ; 124.57$;

$124.79 ; 135.77 ; 136.48 ; 138.02 ; 144.87 ; 166.96 ; 178.53$.

4-oxo-1,4-dihydroquinoline-3-carboxylic acid (5b). White solid, hygroscopic. ${ }^{1} \mathrm{H}$ NMR $\left(400 \mathrm{MHz}, \mathrm{D}_{2} \mathrm{O}\right): \delta_{(\mathrm{ppm})}$ $7.33\left(\mathrm{ddd}, 1 \mathrm{H}_{6}, J=7.9,7.5\right.$ and $\left.1.1 \mathrm{~Hz}\right) ; 7.56\left(\mathrm{ddd}, 1 \mathrm{H}_{\mathbf{8}}, J=\right.$ 7.7, 7.5 and $1.4 \mathrm{~Hz}) ; 7.65$ (d, $1 \mathrm{H}_{7}, J=8.2$, broad signal); 8.16 (dd, $1 \mathrm{H}_{5}, J=8.2$ and $1.2 \mathrm{~Hz}$, broad signal); $8.47\left(\mathrm{~s}, 1 \mathrm{H}_{2}\right) .{ }^{13} \mathrm{C}$ NMR $\left(\mathrm{D}_{2} \mathrm{O}\right): \delta{ }_{(\mathrm{ppm})} 117.93 ; 123.50 ; 124.51 ; 126.23 ; 127.40$; $130.06 ; 148.92 ; 152.29 ; 172.40 ; 177.08$.

6-methoxy-4-oxo-1,4-dihydroquinoline-3-carboxylic acid (5c). White solid, hygroscopic. ${ }^{1} \mathrm{H}$ NMR $(400 \mathrm{MHz}$, DMSO- $\left.d_{6}\right): \delta_{(\mathrm{ppm})} 3.90\left(\mathrm{~s}, 3 \mathrm{H}_{10}\right) ; 7.51\left(\mathrm{dd}, 1 \mathrm{H}_{7}, J=2.9\right.$ and $9.1 \mathrm{~Hz}) ; 7.63\left(\mathrm{~d}, 1 \mathrm{H}_{5}, J=2.9 \mathrm{~Hz}\right) ; 7.77\left(\mathrm{~d}, 1 \mathrm{H}_{8}, J=9.0 \mathrm{~Hz}\right)$; $8.81\left(\mathrm{~s}, 1 \mathrm{H}_{2}\right) ; 13.40\left(\mathrm{~s}, 1 \mathrm{H}_{1}\right) ; 15.53\left(\mathrm{~s}, 1 \mathrm{H}_{11}\right) .{ }^{13} \mathrm{C} \mathrm{NMR}$ $\left(\mathrm{DMSO}-d_{6}\right): \delta_{\text {(ppm) }} 56.17 ; 104.64 ; 107.37 ; 121.89 ; 124.86$; $126.14 ; 134.58 ; 143.86 ; 157.92 ; 167.05 ; 177.95$.

6-chloro-4-oxo-1,4-dihydroquinoline-3-carboxylic acid (5d). White solid, hygroscopic. ${ }^{1} \mathrm{H}$ NMR (400 MHz, DMSO- $\left.d_{6}\right): \delta_{(\mathrm{ppm})} 7.87\left(\mathrm{~d}, 1 \mathrm{H}_{8}, J=8.9 \mathrm{~Hz}\right) ; 7.91\left(\mathrm{dd}, 1 \mathrm{H}_{7}, J=\right.$ 2.4 and $8.8 \mathrm{~Hz}) ; 8.18\left(\mathrm{~d}, 1 \mathrm{H}_{5}, J=2.2 \mathrm{~Hz}\right) ; 8.91\left(\mathrm{~s}, 1 \mathrm{H}_{2}\right)$; $13.55\left(\mathrm{~s}, 1 \mathrm{H}_{1}\right) 14.97\left(\mathrm{~s}, 1 \mathrm{H}_{11}\right) .{ }^{13} \mathrm{C} \mathrm{NMR}\left(\mathrm{DMSO}-\mathrm{d}_{6}\right): \delta{ }_{(\mathrm{ppm})}$ $108.46 ; 122.53 ; 124.42 ; 126.05 ; 131.30 ; 134.44 ; 138.61$; $146.04 ; 166.42 ; 177.69$.

6-bromo-4-oxo-1,4-dihydroquinoline-3-carboxylic acid (5e): White solid, hygroscopic. ${ }^{1} \mathrm{H}$ NMR $(400 \mathrm{MHz}$, DMSO- $\left.d_{6}\right): \delta_{(\mathrm{ppm})} 7.78\left(\mathrm{~d}, 1 \mathrm{H}_{8}, J=9.0 \mathrm{~Hz}\right) ; 8.04\left(\mathrm{dd}, 1 \mathrm{H}_{7}, J=\right.$ 2.3 and $8.8 \mathrm{~Hz}) ; 8.36\left(\mathrm{~d}, 1 \mathrm{H}_{5}, J=2.2 \mathrm{~Hz}\right) ; 8.95\left(\mathrm{~s}, 1 \mathrm{H}_{2}\right)$; $13.55\left(\mathrm{~s}, 1 \mathrm{H}_{1}\right) ; 15.00\left(\mathrm{~s}, 1 \mathrm{H}_{11}\right) .{ }^{13} \mathrm{C} \mathrm{NMR}\left(\mathrm{DMSO}-\mathrm{d}_{6}\right): \delta{ }_{(\mathrm{ppm})}$ $108.55 ; 119.41 ; 122.58 ; 126.37 ; 127.58 ; 137.05 ; 138.87$; $146.08 ; 166.39 ; 177.58$.

6-iodo-4-oxo-1,4-dihydroquinoline-3-carboxylic acid (5f): White solid, hygroscopic. ${ }^{1} \mathrm{H}$ NMR (400 MHz, DMSO$\left.d_{6}\right): \delta_{(\mathrm{ppm})} 7.64\left(\mathrm{~d}, 1 \mathrm{H}_{8}, J=8.8 \mathrm{~Hz}\right) ; 8.17\left(\mathrm{dd}, 1 \mathrm{H}_{7}, J=2.0\right.$ and $8.8 \mathrm{~Hz}) ; 8.56\left(\mathrm{~d}, 1 \mathrm{H}_{5}, J=1.8 \mathrm{~Hz}\right) ; 8.92\left(\mathrm{~s}, 1 \mathrm{H}_{2}\right) ; 13.57(\mathrm{~s}$, $\left.1 \mathrm{H}_{1}\right) ; 15.03\left(\mathrm{~s}, 1 \mathrm{H}_{11}\right) .{ }^{13} \mathrm{C} \mathrm{NMR}\left(\mathrm{DMSO}-\mathrm{d}_{6}\right): \delta$ (ppm) 91.98 ; $108.59 ; 122.26 ; 126.57 ; 133.83 ; 139.21 ; 142.39 ; 145.82$; $166.44 ; 177.43$.

\section{CONFLICT OF INTEREST}

The authors confirm that this article content has no conflict of interest.

\section{ACKNOWLEDGEMENTS}

This work was supported financially by CONICET and SECyT-UNC. Thanks are given to Dr. Novruz Akhmedov (West Virginia University, USA) and Dr. Gloria Bonetto (University of Cordoba) for the good NMR experiments of quinolone compounds.

\section{SUPPLEMENTARY MATERIAL}

Description: Detailed experimental procedures and characterization analysis of products.

Supplementary material is available on the publishers Web site along with the published article.

\begin{tabular}{lll}
\multicolumn{2}{l}{ ABBREVIATIONS } \\
PPA & $=$ & Polyphosphoric acid \\
DMF & $=$ & $N, N$-Dimethylformamide \\
DCB & $=$ & $1,2-$ Dichlorobenzene \\
DPE & $=$ & Diphenyl ether \\
TMS & $=$ & Tetramethylsilane \\
DMSO & $=$ & Dimethyl sulfoxide \\
TFA & $=$ & Trifluoroacetic acid
\end{tabular}

\section{REFERENCES}

[1] Wube, A.A.; Hüfner, A.; Thomaschitz, C.; Blunder, M.; Kollroser, M.; Bauer, R.; Bucar, F. Design, synthesis and antimycobacterial activities of 1-methyl-2-alkenyl-4(1H)-quinolones. Bioorg. Med. Chem., 2011, 19(1), 567-579.

[2] Qi-Lun, L.; Qiu-Lian, L.; Xiang-Dong, F.; Yong-Ming, Z. MetalFree intramolecular amination: one-pot tandem synthesis of 3substituted 4-quinolones. ACS Comb. Sci., 2011, 13(1), 19-23.

[3] Edmont, D.; Rocher, R.; Plisson, C.; Chenault, J. Synthesis and evaluation of quinoline carboxyguanidines as antidiabetic agents. Bioorg. Med. Chem. Lett., 2000, 10(16), 1831-1834.

[4] Xia, Y.; Yang, Z.Y.; Xia, P.; Bastow, K.F.; Nakanishi, Y.; Nampoothiri, P.; Hamel, E.; Brossi, A.; Lee, K.H. Antitumor Agents. Part 226: synthesis and cytotoxicity of 2-phenyl-4-quinolone acetic acids and their esters. Bioorg. Med. Chem. Lett., 2003, 13(17), 2891-2893.

[5] Cross, R.M.; Monastyrskyi, A.; Mutka, T.S.; Burrows, J.N.; Kyle, D.E.; Manetsch, R. Endochin optimization: structure-activity and structure-property relationship studies of 3-substituted 2-methyl4(1H)-quinolones with antimalarial activity. J. Med. Chem., 2010, 53(19), 7076-7094.

[6] Kadnikov, D.V.; Larock, R.C. Palladium-catalyzed carbonylative annulation of terminal alkynes: synthesis of coumarins and 2quinolones. J. Organomet. Chem., 2003, 687(2), 425-435.

[7] Khan, A.T.; Kumar Das, D.; Khan, M.M. Ferric sulfate $\left[\mathrm{Fe}_{2}\left(\mathrm{SO}_{4}\right)_{3} \cdot \mathrm{xH}_{2} \mathrm{O}\right]$ : an efficient heterogeneous catalyst for the synthesis of tetrahydroquinoline derivatives using Povarov reaction. Tetrahedron Lett., 2011, 52(35), 4539-4542.

[8] Chebanov, V.A.; Saraev, V.E.; Desenko, S.M.; Chernenko, V.N.; Shishkina, S.V.; Shishkin, O.V.; Kobzar, K.M.; Kappe, C.O. OnePot, multicomponent route to pyrazoloquinolizinones. Org. Lett., 2007, 9(9), 1691-1694.

[9] Bougrin, K.; Loupy, A.; Soufiaoui, M. Microwave-assisted solventfree heterocyclic synthesis. J. Photochem. Photobiol., C, 2005, 6(23), 139-167.

[10] Lidström, P.; Tierney, J.; Wathey, B.; Westman, J. Microwave assisted organic synthesis-a review. Tetrahedron, 2001, 57(45), 9225-9283.

[11] Pepino, A.; Peláez, W.; Moyano, E.; Argüello, G. Highly efficient dehydrogenation of 5-benzyl-3-phenyl-2-thioxoimidazolidin-4-one: microwave versus flash vacuum pyrolysis conditions. Eur. J. Org. Chem., 2012, 18, 3424.

[12] Turina, A.; Quinteros, G.; Caruso, B.; Moyano, E.; Perillo, M. Surface active benzodiazepine-bromo-alkyl conjugate for potential $\mathrm{GABA}_{\mathrm{A}}$-receptor purification. Org. Biomol. Chem., 2012, 9, 57375747.

[13] López Rivilli, M.J.; Moyano, E.L.; Yranzo, G.I. An alternative approach toward 2-aryl-2H-pyrazolo[4,3-c]-quinolin-3-ones by a multistep synthesis. Tetrahedron Lett., 2010, 51(3), 478-481.

[14] Černuchová, P.; Vo-Thanh, G.; Milata, V.; Loupy, A. Solvent-free synthesis of quinolones derivatives. Heterocycles, 2004, 64(1), 177-191.

[15] Cao, X; You, Q.D.; Lia, Y.-Z.; Yanga, Y.; Wanga, X.J. Microwave-assisted simple synthesis of substituted 4-quinolone derivatives. Synth. Commun., 2009, 39(24), 4375-4383.

[16] Razzaq, T.; Kappe, C.O. Rapid preparation of pyranoquinolines using microwave dielectric heating in combination with fractional product distillation. Tetrahedron Lett., 2007, 48(14), 2513-2517. 
[17] Jia, C.S.; Dong, Y.W.; Tu, S.J.; Wang, G.W. Microwave-assisted solvent-free synthesis of substituted 2-quinolones. Tetrahedron, 2007, 63(4), 892-897.

[18] Albretch, M.; Osetska, O.; Fröhlich, R.; Bolm, C. Microwaveassisted preparation of quinolone and quinoline derivatives. Synlett, 2010, 7, 1081-1084.

[19] Suena, Y.F.; Robinsa, L.; Yang, B; Verkmanb, A.S.; Nantza, M.H.; Kurth, M.J. Sulfamoyl-4-oxoquinoline-3-carboxamides: novel potentiators of defective $\Delta \mathrm{F} 508$-cystic fibrosis transmembrane conductance regulator chloride channel gating. Bioorg. Med. Chem. Lett., 2006, 16(3), 537-540.

[20] Westman, J. Speed and efficiency in the production of diverse structures: microwave-assisted multi-component reactions. In: $M i-$ crowave Assisted Organic Synthesis; Tierney, J.P.; Lidström, P., Eds.; Blackwell Publishing Ltd: Oxford, 2005, pp. 102-132.

[21] Ding, D.; Li, X.; Wang, X.; Du, Y.; Shen, J. Microwave-assisted rapid and straightforward synthesis of 2-aryl-4-quinolones from acylated 2'-aminoacetophenones. Tetrahedron Lett., 2006, 47(39), 6997-6999.
[22] Stadler, A.; Pichler, S.; Horeis, G.; Kappe, C.O. Microwaveenhanced reactions under open and closed vessel conditions. A case study. Tetrahedron, 2002, 58(16), 3177-3183.

[23] Lange, J.H.M.; Verveer P.C.; Osnabrug S.J.M.; Visser, G.M. Rapid microwave-enhanced synthesis of 4-hydroxyquinolinones under solvent-free conditions. Tetrahedron Lett., 2001, 42(7), 1367-1369.

[24] Massari, S.; Daelemans, D.; Manfroni, G.; Sabatini, S.; Tabarrini, O.; Pannecouque, C.; Cecchetti, V. Studies on anti-HIV quinolones: new insights on the C-6 position. Bioorg. Med. Chem., 2009, 17(2), 667-674.

[25] Pasquini, S.; De Rosa, M.; Ligresti, A.; Mugnaini, C.; Brizzi, A.; Caradonna, N.; Cascio, M.; Bolognini, D.; Pertwee, R.; Di Marzo, V.; Corelli, F. Investigations on the 4-quinolone-3-carboxylic acid motif. Synthesis and pharmacological evaluation of 7-substituted quinolone-3-carboxamide derivatives as high affinity ligands for cannabinoid receptors. Eur. J. Med. Chem., 2012, 58(1), 30-43.

[26] Mugnaini, C.; Pasquini, S.; Corelli, F. Investigations on the 4quinolone-3-carboxylic acid motif. Modulation of the physicochemical profile of a set of potent and selective CB2 ligands through a bioisosteric approach. Curr. Med. Chem., 2009, 16(22), 1746-1767. 